\title{
Emotional Quotient, Family Environment and Their Influences on Teacher Performance
}

\author{
Apeles Lexi Lonto*, Sjamsi Pasandaran, Theodorus Pangalila \\ Pancasila and Civic Education Department of Social Science Faculty \\ Universitas Negeri Manado \\ Manado, Indonesia \\ *lexi.lonto@unima.ac.id
}

\begin{abstract}
This study aims to examine the problem of teacher performance weakness by studying emotional quotient and family environment, and its positive influence on teacher performance. The data was collected through questionnaire from 61 teachers and 183 students, which selected by multistage sampling technique. The data were analyzed descriptively and inferentially with multiple regression and correlation analysis. The result showed that: (1) emotional quotient has a positive effect on teacher's performance, (2) religiosity has a positive effect on teacher's performance, (3) family environment has a positive effect on teacher's performance, and (4) emotional quotient and family environment have simultaneously effect on teacher's performance. The findings suggest that teacher performance could be enhanced by enhancing emotional quotient and religiosity as well as family environment conduciveness.
\end{abstract}

Keywords-emotional quotient; family environment; teacher performance

\section{INTRODUCTION}

This research is based on issues concerning the low performance of teachers, whereas teacher performance is an essential element in the learning process. Various studies show that high teacher performance or high-performance influence on student achievement learning even strongly influence student's achievement [1]. Other findings found that teacher performance reflects teacher competence in both pedagogic competence, professional competence, social competence, and even personality competence, which influences student achievement [2]. In another perspective, research findings reinforce teacher pedagogical competence influences that teacher performance. It found that pedagogical didactic, personal, and human support affects teacher performance [3]. In addition to teacher competence factors, other studies have found that psychological factors such as teacher satisfaction affect teacher performance [4]. Another psychological aspect is the finding of the influence of teachers' emotional intelligence on job performance. The emotional intelligence aspects studied by Mohamad and Jais are emotional intelligence dimensions that include self-regulation, self-awareness, self-motivation, and social skills or relationship management skills [5]. However, there is still little research related to teacher performance. Teacher performance has multi-dimension both psychologist dimension and social dimension.
This study aims to examine the psychological dimensions and social dimensions of teacher performance. The observed psychological dimension is emotional intelligence or emotional quotient that includes the ability to deal with frustration, emotional control, optimism, and empathy. The social dimension studied here is the family environment as the closest social environment of the teacher. Thus, this study investigates how emotional quotient and family environment affect teacher performance.

The study of factors affecting teacher performance has been widely practiced. It is evident that teacher performance is a multidimensional variable. The teacher's performance has a psychological dimension about the relationship between teachers' motives, attitudes and performance [6]. Similarly, findings on self-efficacy that turned out to affect the performance of teachers [7]. However, other research results show the social dimensions of teacher performance, which found that there is an effect of social connections on job engagement and performance. Although there have been many studies of the psychological dimensions and social dimensions of teacher performance, they still do not cover the whole range of aspects, both psychological and social dimensions. In fact, the problem of teacher performance has a broad aspect of the problem. Therefore, this study will increase the breadth and depth of the study on the aspects of both the psychological dimension and the social dimension of teacher performance. As a study, the results of this study will enrich and provide theoretical and empirical understanding and awareness of aspects related to teacher performance.

The research was conducted by using a quantitative approach by examining the psychological dimension of teacher's namely emotional quotient and social dimension of a family environment. The emotional quotient aspects studied include aspects of the ability to control frustration, the ability to control emotions, the spirit of optimism, and the sense of empathy. While the aspects of the family environment studied include openness, discipline, cooperation, and adaptability. This research is useful to provide an overview of the effect of emotional intelligence and the state of the family environment on teacher performance. The research results are useful for the development of psychological aspects and sociological aspects that affect the performance of teachers. For practical purposes, 
the results of this research are useful for decision-making guidance of teacher professionalism.

\section{THEORITICAL}

The study of teacher performance in this study is viewed explicitly from two dimensions: psychological dimension and social dimension. Various studies on the psychological dimension show that there are psychological aspects that affect the performance of teachers. The psychological aspect to be studied is the aspect of emotional intelligence. Emotional quotient is understood as a psychological condition that can encourage the self-efficacy of someone who can encourage and improve one's performance. Emotional quotient is understood as the ability of self-esteem, self-awareness of the ability, ability and potential self; self-regulation which refers to the ability to control oneself, and motivation refers to one's motivation in doing something. These conditions by Joanne are seen intra personal EQ, whereas about others or interpersonal EQ refers to the ability to empathy and social skills. EQ both intrapersonal and interpersonal are significant factors and will be a motivational force for the attitude and behavior of a person as a performance. Various studies have shown that EQ influences people's attitudes and performance in areas such as influence on leadership performance [8], teaching performance [9], teacher efficacy [10], and influence on teacher quality teaching [11].

The social dimension of teacher performance is seen from the perspective of the teacher's social environment, especially the immediate environment of the family. The role of the environment is known to have a very significant effect on a person. From various studies can be identified family conditions that affect the performance of teachers. The first is the problem of work, especially the complexity of the work both at home and work in the office, teachers must be able to facilitate various types of work [12]. The complexity of the work can lead to conflicts with teachers that have implications for teacher performance in schools [13]. Second. Another condition is the relationship between the families. Several family situations affect a teacher in carrying out his teaching duties. The family situation is among others the openness of relations between family members.

\section{METHOD}

This research is explanatory research, with survey method. The research variables are emotional intelligence $\left(\mathrm{X}^{1}\right)$, family environment $\left(\mathrm{X}^{2}\right)$, and teacher performance $(\mathrm{Y})$. The study was conducted on 61 high school Civic Education teachers in North Sulawesi, selected using a multi-stage sampling technique. The technique of collecting data is done by using a questionnaire instrument or questionnaire. The instrument of this research includes three research variables, namely: (1) Instrument for teacher performance variable; (2) instruments for emotional intelligence variables; (3) instruments for family environment variables. The research instruments are arranged for each variable using a measurement scale that is Likert scale. Each of the research instruments composed contains statements categorized as positive statements and negative statements. To determine the validity and reliability of the research instrument that was developed, firstly tested the teachers of Civics High
School who are not respondents or members of the research sample. Validity testing is done by using correlation analysis between grain scores with the total score of the instrument. The research hypothesis is formulated as follows:

Emotional intelligence has a positive effect on teacher performance, with statistical notation as follows

$$
\begin{aligned}
& \text { H0: } \beta 1 \leq 0 \\
& \text { H1: } \beta 1>0
\end{aligned}
$$

Family environment has a positive effect on teacher performance with statistics notation as follows:

$$
\begin{aligned}
& \text { H0: } \beta 2 \leq 0 \\
& \text { H1: } \beta 2>0
\end{aligned}
$$

Emotional quotient and family environment together positively influence teacher performance, with statistical notation as follows

$$
\begin{aligned}
& \text { H0: } \beta 2 \leq 0 \\
& \text { H1: } \beta 2>0
\end{aligned}
$$

Statistical analysis used is Product Moment correlation of

\begin{tabular}{|c|c|c|c|c|c|c|}
\hline \multirow[t]{2}{*}{ Model } & \multicolumn{2}{|c|}{$\begin{array}{l}\text { Unstandardize } \\
\text { d Coefficients }\end{array}$} & \multirow{2}{*}{$\begin{array}{c}\begin{array}{c}\text { Standardized } \\
\text { Coefficients }\end{array} \\
\text { Beta }\end{array}$} & \multirow[t]{2}{*}{$\begin{array}{l}\text { count } \\
(\alpha=0,05)\end{array}$} & \multirow{2}{*}{$\mathbf{t}$} & \multirow{2}{*}{ Sig. } \\
\hline & $B$ & $\begin{array}{c}\text { Std. } \\
\text { Error }\end{array}$ & & & & \\
\hline $\begin{array}{l}\text { (Constant) = } \\
11.366\end{array}$ & - & 4.401 & - & - & 2,582 & .012 \\
\hline $\begin{array}{l}\text { Emotional } \\
\text { Intelligence }\end{array}$ & .456 & .177 & .255 & 1,67 & 2,581 & .012 \\
\hline $\begin{array}{l}\text { Family } \\
\text { environment }\end{array}$ & 1.112 & .191 & .570 & 1,67 & 5,812 & .000 \\
\hline $\begin{array}{l}\text { Dependent } \\
\text { Variable: } \\
\text { Teacher } \\
\text { Performance }\end{array}$ & \multicolumn{2}{|c|}{$\mathrm{R}_{\mathrm{y} 1,2,3}=0,993$} & \multicolumn{4}{|l|}{$\mathrm{R}_{\mathrm{y} 1,2,3}^{2}=0,985$} \\
\hline
\end{tabular}
Pearson. To test the reliability of the instrument used Cronbach Alpha analysis. Data analysis techniques used are descriptive and inferential statistical analysis techniques.

\section{RESUlT AND DISCUSSION}

TABLE I. RESUlts OF DATA PROCESSING

The results of data processing in table 1 show the findings of the research. First, the results of hypothesis testing one show that emotional intelligence has a positive effect on teacher performance with $t$ count (2.581) $>t$ table (1.67) at significance level $\alpha=0.05$. This indicates that the better the emotional maturity of teachers leads to increased teacher performance. Goleman's emotional intelligence is the ability to help and control her feelings and others and use those feelings to blend thoughts and actions [14]. The emotional maturity of the teacher makes the teacher wiser in making decisions, can communicate with many people, and has a high sense of moral responsibility to his work which will certainly improve the performance of teachers. Goleman states that the world of work demands $80 \%$ of emotional intelligence compared to only $20 \%$ of intellectual intelligence [14]. As a leader in the management of the learning process, teachers need to have emotional intelligence and continuously seek to enhance emotional 
intelligence, thus helping teachers in the interaction process in the classroom. This is important because the learning process is essentially a process of educational interaction between teachers and students. Teachers will become figures to emulate, so teachers who lose self-control or who have low emotional intelligence will experience difficulty in the process of educational interaction. A leader further underpins his actions by emphasizing the use of his Emotional Intelligence. About social relations as an indicator of emotional intelligence. Cohesiveness is the power of interaction among members of a group. Cohesiveness is shown in the form of hospitality among group members; they are usually happy to be together. Each member feels free to express opinions and suggestions. As it relates to empathy, asserts that empathetic people can understand the motivations and experiences of others, their feelings and attitudes, and their hopes and desires for the future.

Second, hypothesis 2 testing shows that family environment has a positive effect on teacher performance with $\mathrm{t}$ count $(5,812)>\mathrm{t}$ table $(1.67)$ at significance level $\alpha=0,05$. This result shows that teachers who are in a good family environment will cause teacher performance to increase. Referring to the findings of Marco Depolo and Gürcü Erdamar, Hüsne Demirel can be explained several factors of family conditions that affect the performance of teachers [12]. These factors can be work factors as well as relationships within the family. Because teachers are in a harmonious and functioning family environment, teachers will display good attitude, love students, respect students, provide guidance with affection, protect students from falling into immoral deeds. Teacher attitude like this affects the performance of teachers in carrying out their work activities. Teachers can control and move optimally the potential of intelligence that exists in the emotional brain (limbic system).

Third, the result of hypothesis testing shows that there is the influence of emotional intelligence positive and family environment together to teacher performance with $\mathrm{f}$ count $(1270,927)$ bigger than $\mathrm{f}$ table $(2,76)$ at significance level $\alpha=$ 0,05 . Positive influence means that the higher the emotional intelligence and the family environment the higher the performance of teachers. Also, emotional intelligence and family environments are factors/variables that can not be ignored in influencing teacher performance. The results showed that $98.50 \%$ of teacher performance is determined by emotional intelligence and family environment together. Performance is an evaluation of the outcome of a person's behavior that includes the determination of how well and how badly a person has completed his job or task. Emotional intelligence is an emotional ability to effectively manage oneself with sensitivity to conscience, to be used in relationships with people and performing everyday actions. According to Robbins performance is an evaluation of the results of a person's behavior. It involves determining how well a person has accomplished a task or a job. Performance is an evaluation of the outcome of a person's behavior that includes the determination of how well and how well a person has completed his job or task. Teacher performance is influenced by emotional intelligence because teachers who have stable emotions will be wiser in making decisions, can communicate with others, and have a sense of high moral responsibility to carry out the tasks as education, faculty, facilitators, moderators, and counselors learn for students.

\section{CONCLUSION}

Based on the results of research and discussion, it is concluded that emotional intelligence has a positive effect on teacher performance. Good teacher emotional intelligence will improve teacher performance. The family environment positively affects teacher performance, meaning that if a conducive family environment improves teacher performance; and together emotional intelligence and family environment together positively affect the performance of teachers, meaning that if the conducive environment of their families sustains the teacher's emotional intelligence, it will improve teacher performance. It is recommended that guidance and improvement of teacher performance be done with attention to strengthening emotional quotient and family environment.

\section{ACKNOWLEDGMENTS}

We would like to say thanks to the Rector of Manado State University who has facilitated the research and writing of this article, also to our fellow research team and writers. Thanks also to the Committee of Annual Civic Education Conference (ACEC) and the Indonesia University of Education which has facilitated the publication of this article.

\section{REFERENCES}

[1] B. Naoreen, et al., "Gender Wise Comparison of Trained and Untrained Teachers' Performance on Students' Learning Achievement in Mathematics," Procedia - Social and Behavioral Sciences. Elsevier B.V., vol. 116, pp. 3016-3020, 2014.

[2] R. Bakar, "The influence of professional teachers on Padang vocational school students' achievement," Kasetsart Journal of Social Sciences. Elsevier Ltd, vol. 39, no. 1, pp. 67-72, 2018

[3] P. Vinhais and M. Abelha, "Supervision and Appraisal of Foreign Language Teachers' Performance," Procedia - Social and Behavioral Sciences. Elsevier B.V., vol. 174, pp. 783-790, 2015.

[4] I.A. Rudaleva, I.A. Kabasheva, and E. Kovaleva, "Factors Satisfaction Assessment of Teachers Professional Activity," Procedia - Social an Behavioral Sciences. Elsevier B.V., vol. 152, no. 843, pp. 1114-1120, 2014.

[5] M. Mohamad and J. Jais, "Emotional Intelligence and Job Performance: A Study among Malaysian Teachers," Procedia Economics and Finance. Elsevier B.V., vol. 35, pp. 674-682, 2016.

[6] Bukidnon, Philippines, Gladys S. Escarlos, D.A.T., "Motives, Attitudes, and Performance Of Teacher Education Students In Southern," International journal of scientif \& technology Research, vol. 6, no. 10, pp. 20-25, 2017.

[7] V. Lantik, "The Professional Performance and Self-Efficacy of Physics Teachers Senior High Schools of Bachelor Graduate of Physics Education in Kupang," International Journal of Scientific \& Technology Research, vol. 4, no. (1), pp. 20-31, 2016.

[8] G. VanderPal, "Global Leadership and Emotional Quotient," The Journal of Applied Business and Economics, vol. 16, no. 5, pp. 137-149, 2014

[9] E.S. Hosseini and M. Zirak, "The relationship between emotiona intelligence and organizational citizenship behavior and organizational commitment in city secondary school teachers Torbat-h," International 
Research Journal of Applied and Basic Sciences, vol. 10, no. 7, pp. 962971, 2016.

[10] D.A. Adeyemo and A.R. Chukwudi, "Emotional intelligence and teacher efficacy as predictors of teacher effectiveness among pre-service teachers in some Nigerian universities," International Journal of Evaluation and Research in Education, vol. 3, no. 2, pp. 85-90, 2014.

[11] S. Dev, S. Nair, and A. Dwivedi, "Emotional Intelligence of Instructors and the Quality of Their Instructional Performance," International Education Studies, vol. 9, no. 5, pp. 40, 2016.
[12] M. Depolo and I. Bruni, "Teachers' Facilitation Between Work and Family Roles: Myth or Reality?," Procedia - Social and Behavioral Sciences. Elsevier B.V., vol. 186, pp. 886-893, 2015.

[13] G. Erdamar and H. Demirel, "Investigation of Work-family, Familywork Conflict of the Teachers," Procedia - Social and Behavioral Sciences. Elsevier B.V., vol. 116, pp. 4919-4924, 2014.

[14] D. Goleman, Working with Emotional Intelligence: Kecerdasan Emosi untuk Mencapai Puncak Prestasi. Jakarta: Gramedia, 1999. 